\title{
Brazilian Journal \\ of Chemical

\section{CITRIC ACID PRODUCTION BY SOLID-STATE FERMENTATION ON A SEMI-PILOT SCALE USING DIFFERENT PERCENTAGES OF TREATED CASSAVA BAGASSE}

\author{
F. C. Prado ${ }^{1}$, L. P. S. Vandenberghe ${ }^{1}$, A. L. Woiciechowski ${ }^{1}$, \\ J. A. Rodrígues-León ${ }^{2}$ and C. R. Soccol ${ }^{1, *}$ \\ ${ }^{1}$ Universidade Federal do Paraná, Departamento de Engenharia Química, Laboratório de Processos Biotecnológicos, \\ Cx. P. 19011, CEP 81531-990, Curitiba - PR, Brazil. \\ ${ }^{2}$ Instituto Cubano de Investigación de los Derivados de la Cana de Azúcar (ICIDCA), \\ P. O. Box 4026, La Habana, Cuba. \\ E-mail: soccol@ufpr.br
}

(Received: October 20, 2004 ; Accepted: June 1, 2005)

\begin{abstract}
Citric acid is commercailly important product used in several industrial processes. Solid-state fermentation (SSF) has become an alternative method for citric acid production using agro-industrial residues such as cassava bagasse (CB). Use of CB as substrate can avoid the environmental problems caused by its disposal in the environment. The aim of this work was to verify the effect of different percentages of gelatinized starch in $\mathrm{CB}$ on production of citric acid by SSF in horizontal drum and tray-type bioreactors. Gelatinization was used in order to make the starch structure more susceptible to consumption by the fungus. The best results $(26.9 \mathrm{~g} / 100 \mathrm{~g}$ of dry CB) were obtained in horizontal drum bioreactor using $100 \%$ gelatinized CB, although the tray-type bioreactor offers advantages and shows promise for large-scale citric acid production in terms of processing costs.

Keywords: Citric acid; Solid-state fermentation; Gelatinized starch; Semi-pilot scale.
\end{abstract}

\section{INTRODUCTION}

With an estimated annual production of about $1,000,000$ tons, citric acid is one of fermentation products with the highest level of production worldwide (Soccol et al., 2003). Considerable amounts of citric acid are required in several industrial processes (Jianlong, 2000). The food industry consumes about $70 \%$ of the total citric acid production, while other industries consume the remaining 30\% (Yokoya, 1992; Pandey et al., 2001).

Commercially production of citric acid is generally by submerged fermentation of sucrose or molasses using the filamentous fungus Aspergillus niger (Röhr et al., 1983; Vandenberghe et al., 2000b). During the past twenty years, interest in the use of solid-state fermentation (SSF) as an alternative to submerged fermentation has been increasing. SSF, often referred to as the Koji process, is the simplest method for citric acid production. It is characterized by the development of microorganisms in a low-water-activity environment on a nonsoluble material acting as both nutrient source and physical support (Soccol, 1994; Vandenberghe et al., 2000b). SSF offers numerous advantages, starting with the use of agro-industrial residues. This process has lower energy requirements, produce less wastewater and is environmental-friendly as it resolves the problem of solid wastes disposal (Vandenberghe et al., 2000b; Pandey, 2003).

*To whom correspondence should be addressed 
There has been an increasing trend towards efficient utilization of agro-industrial residues and byproducts (Soccol and Vandenberghe, 2003). Many of them have been studied with SSF techniques for their potential use as substrates for citric acid production (Vandenberghe et al., 2000a). A cost reduction in citric acid production can be achieved by using less expensive substrates, such as apple and grape pomace, carrot waste, carob pod, orange and pineapple waste, cassava bagasse, coffee husk, kiwifruit peel, mussel processing wastes, okara (soy residue), rice and wheat bran (Hang and Woodams, 1984, 1985, 1987; Aravantinos-Zafiris et al., 1994; Khare et al., 1995; Pandey et al., 2000; Vandenberghe, 2000; Soccol et al., 2003). These residues are very well adapted to solidstate cultures due to their cellulosic and starchy nature.

Cassava (Manihot esculenta Crantz) is widely produced in Brazil, which occupies the second place in the world ranking of cassava production, with 22.6 million tons (Alves and Silva, 2004). Cassava bagasse $(\mathrm{CB})$ is a solid residue generated in the starch extraction process (Vandenberghe et al., 2000b; Cereda, 1994). Its disposal in the environment can causes serious pollution problems due to its high organic material content and biodegradability (Pandey et al., 2000). Utilization of CB by microbial fermentation has been shown to be promising because it would provide an alternative substrate and solve pollution problems (Soccol and Vandenberghe, 2003).

The aim of the present work was to test the effect of thermal treatment of $\mathrm{CB}$ starch on citric acid production by SSF. Different percentages of treated and untreated CB were evaluated. SSF was carried out in two kinds of semi-pilot bioreactors: horizontal drum and tray-type bioreactors.

\section{MATERIAL AND METHODS}

\section{Microorganism and Inoculum}

A strain of Aspergillus niger LPB 21 was grown on potato dextrose agar (PDA) slants at $28{ }^{\circ} \mathrm{C}$ for seven days. Slants were preserved at $4{ }^{\circ} \mathrm{C}$ for up to two months.

The spores of A. niger were produced in $250 \mathrm{~mL}$ Erlenmeyer flasks containing $40 \mathrm{~mL}$ PDA medium. The medium was inoculated with spores from the stock culture and incubated at $28{ }^{\circ} \mathrm{C}$ for seven days. The spores were recovered by stirring using a solution of Tween $80 \quad 0.01 \%$. The suspension obtained, containing $10^{8}$ spores $/ \mathrm{mL}$, was stored at 4 ${ }^{\circ} \mathrm{C}$ for up to seven days.

\section{Substrate and Thermal Treatment}

Cassava bagasse (CB) was supplied by Agroindustrial Paranaense de Polvilho Ltda. (Paranavaí - PR, Brazil) and used as substrate. Its starch composition was about $55 \%$. CB was ground in a mill and was sieved to obtain a particle size of 0.8 to $2.0 \mathrm{~mm}$.

CB was thermally treated to gelatinize the starch by adding $110 \mathrm{~mL}$ distilled water for $100 \mathrm{~g}$ of dry CB. Samples were heated at $121{ }^{\circ} \mathrm{C}$ for 20 minutes (Vandenberghe, 2000). The effect of starch gelatinization on citric acid production was observed by testing different ratios of treated cassava bagasse (TCB) and untreated cassava bagasse (UTCB) during fermentation $(0: 100 ; 40: 60 ; 60: 40 ; 80: 20 ; 100: 0)$.

\section{Nutrients}

CB was supplemented with a nutritive solution containing $(\mathrm{g} / \mathrm{L}) 2.93$ urea, $1.86 \mathrm{KH}_{2} \mathrm{PO}_{4}$ and 0.0105 $\mathrm{FeSO}_{4} \cdot 7 \mathrm{H}_{2} \mathrm{O}$, which was sterilized at $121{ }^{\circ} \mathrm{C}$ for 15 min. After cooling, methanol (4\% v/v) was added under sterile conditions.

\section{Solid-state Fermentation}

Solid-state fermentation (SSF) on trays was carried out with the initial moisture adjusted to $70 \%$ with the nutritive solution. Substrate was inoculated with the spore suspension containing $10^{7}$ spores/g of dry CB. The pre-inoculated substrate was distributed on trays $\left(0.0045 \mathrm{~m}^{3}\right)$ to obtain bed thicknesses of 2,4 and $6 \mathrm{~cm}$ of $(0.15,0.30$ and $0.45 \mathrm{~kg}$ of dry substrate, respectively). The trays were placed in a room with controlled temperature $\left(28{ }^{\circ} \mathrm{C}\right)$ and a humidity of about $97 \%$. Fermentation was carried out for $120 \mathrm{~h}$.

SSF was also conducted in a horizontal drum (HD) bioreactor with $2 \mathrm{~kg}$ of dry substrate and $60 \%$ of the initial moisture adjusted with the nutritive solution. In this case, initial moisture of the substrate was lower than in the TT bioreactor to avoid the excessive bunching of the substrate particles, which was observed in the first fermentations carried out in the HD bioreactor. The inoculated substrate $\left(10^{7}\right.$ spores/g of dry $\mathrm{CB}$ ) was placed inside the drum. As shown in Figure 1, the drum $\left(0.024 \mathrm{~m}^{3}\right)$ consisted of a shovel coupled to a motor axis that turned at controlled speed. Thus, material was turned three to four times a day. The lower initial moisture (60\%) also makes easier this motion of the substrate and the distribution of air between the particles, avoiding channeling. After 20 hours of fermentation, saturated air was inserted continually into the drum in order to control substrate temperature and moisture (Vandenberghe, 2000). The airflow was maintained at $5 \mathrm{~L} / \mathrm{min}$. Fermentation was carried out at room temperature for $144 \mathrm{~h}$. 


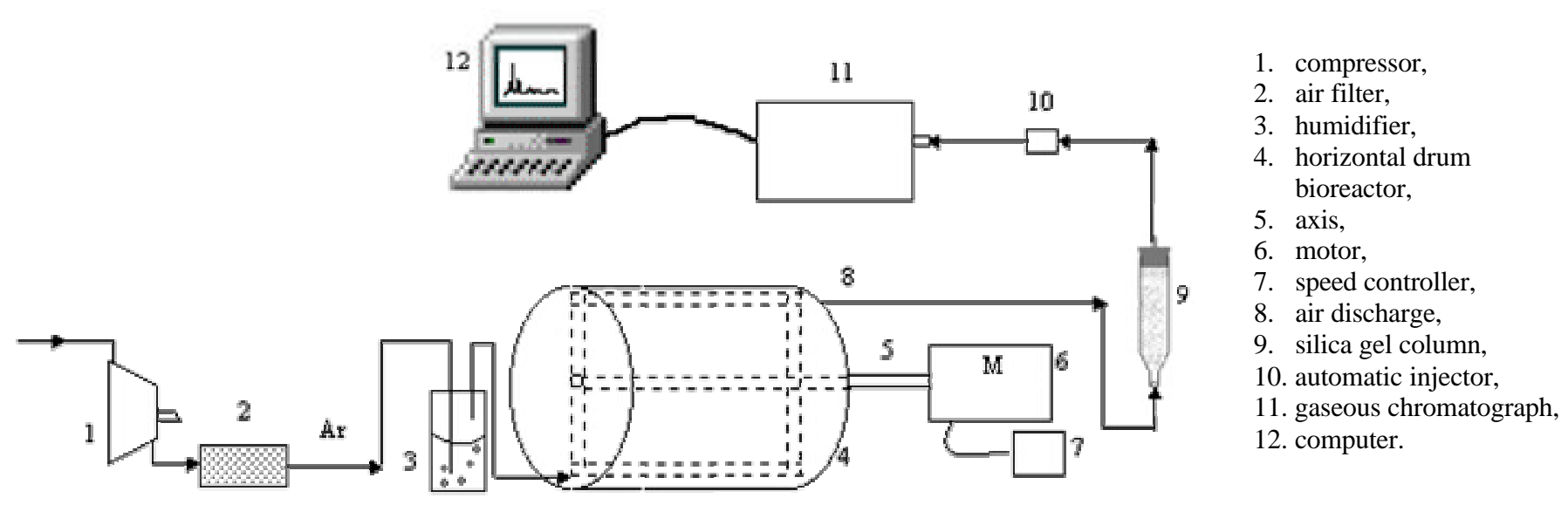

Figure: Outline of the horizontal drum bioreactor and auxiliary equipment:

\section{Kinetics of Citric Acid Production by SSF in the Horizontal Drum Bioreactor}

Every $24 \mathrm{~h}$, samples were collected for evaluation of citric acid production as well as changes in $\mathrm{pH}$, residual starch and cellular biomass. This kinetic study was carried out in the HD bioreactor in order to observe some important aspects of the fermentation and the final yield of the process. The global yield was determined by the ratio of citric acid produced to starch consumed.

\section{Analytical Methods}

Citric acid was extracted by mixing $5 \mathrm{~g}$ fermented samples with $50 \mathrm{~mL}$ of distilled water with a magnetic stirrer for $10 \mathrm{~min}$. The suspension was filtered through filter paper. After determination of $\mathrm{pH}$ using a digital $\mathrm{pHmeter}$, the filtrate obtained was subjected to high performance liquid chromatograph (HPLC) analysis using a Shimadzu LC-10AD. A temperature of $60{ }^{\circ} \mathrm{C}$ and $5 \mathrm{mM} \mathrm{H}_{2} \mathrm{SO}_{4}$ as the mobile phase at a flow-rate of $0.6 \mathrm{~mL} / \mathrm{min}$ were used. Citric acid was detected in the column eluate by differential refractometer (Shimadzu RID-10A). Residual starch was determined using the enzymatic method proposed by the National Starch Chemical Corporation (1985). The cell biomass was experimentally determined by the Stutzer method (Vervack, 1973) and the nitrogen was determined by the Kjeldahl method (São Paulo, 1985). Each analysis was conducted in triplicate.

\section{Respirometric Analysis}

Biomass was estimated by respirometric analysis. The saturated exhaust air from the HD bioreactor was passed through a silica gel column and analyzed by gas chromatography (Shimadzu GC-8A) to determine $\mathrm{O}_{2}$ and $\mathrm{CO}_{2}$ profiles at the gas outlet and relate them to biomass synthesis.

Oxygen uptake rate (OUR) and volumetric flow of $\mathrm{CO}_{2}(\mathrm{~L} / \mathrm{h})$ were estimated by a mass balance. If exhaust airflow $\left(\mathrm{F}_{\text {out }}\right)$ is known and the inlet airflow is $F_{\text {in }}$, the following equations were used:

$$
\begin{aligned}
& \mathrm{V}_{\mathrm{O}_{2} \text { out }}=\left(\frac{\% \mathrm{O}_{2 \text { out }}}{100}\right) \times \mathrm{F}_{\text {out }} \\
& \mathrm{V}_{\mathrm{CO}_{2} \text { out }}=\left(\frac{\% \mathrm{CO}_{2 \text { out }}}{100}\right) \times \mathrm{F}_{\text {out }} \\
& \mathrm{F}_{\text {out }}=\mathrm{V}_{\mathrm{O}_{2} \text { out }}+\mathrm{V}_{\mathrm{CO}_{2} \text { out }}+\mathrm{V}_{\mathrm{N}_{2} \text { out }} \\
& \mathrm{V}_{\mathrm{N}_{2} \text { out }}=\left(\frac{100-\% \mathrm{O}_{2 \text { out }}-\% \mathrm{CO}_{2 \text { out }}}{100}\right) \times \mathrm{F}_{\text {out }}
\end{aligned}
$$

It is known that

$$
\mathrm{V}_{\mathrm{N}_{2} \text { in }}=\frac{79}{100} \times \mathrm{F}_{\text {in }}
$$




$$
\mathrm{V}_{\mathrm{N}_{2} \text { in }}=\mathrm{V}_{\mathrm{N}_{2} \text { out }}
$$

Thus, the following equation relates the inlet and the outlet airflows

$$
\mathrm{F}_{\text {in }}=\frac{\left(100-\% \mathrm{O}_{2 \text { out }}-\% \mathrm{CO}_{2 \text { out }}\right) \times \mathrm{F}_{\text {out }}}{79}
$$

The mass balance for oxygen is given in order to evaluate the volumetric flow of uptake $\mathrm{O}_{2}$ :

$$
\mathrm{V}_{\mathrm{O}_{2} \text { uptake }}=\left(\frac{21}{100}\right) \times \mathrm{F}_{\text {in }}-\left(\frac{\% \mathrm{O}_{2 \text { out }}}{100}\right) \times \mathrm{F}_{\text {out }}
$$

For estimation of OUR and the mass flow of $\mathrm{CO}_{2}$ $(\mathrm{mol} / \mathrm{h})$, it was assumed that the air was an ideal gas,. Corrections were made for temperature conditions for the volumetric flow $\left(\mathrm{V}_{\mathrm{O}_{2} \text { uptake }}\right.$ and $\left.\mathrm{V}_{\mathrm{CO}_{2} \text { out }}\right)$.

Assuming the balance of OUR, the following equation was obtained (Pandey et al., 2001):

$\mathrm{X}_{\mathrm{n}}=\left\langle\mathrm{Y}_{\mathrm{X} / \mathrm{O}} \Delta \mathrm{t}\left\{\frac{1}{2}\left[\left(\frac{\mathrm{dO}_{2}}{\mathrm{dt}}\right)_{\mathrm{t}=0}+\left(\frac{\mathrm{dO}_{2}}{\mathrm{dt}}\right)_{\mathrm{t}=\mathrm{n}}\right]+\sum_{\mathrm{i}=1}^{\mathrm{i}=\mathrm{n}-1}\left(\frac{\mathrm{dO} \mathrm{O}_{2}}{\mathrm{dt}}\right)_{\mathrm{t}=\mathrm{i}}\right\}+\left(1-\frac{\mathrm{a}}{2}\right) \mathrm{X}_{0}-\mathrm{a} \sum_{\mathrm{i}=1}^{\mathrm{i}=\mathrm{n}-1} \mathrm{X}_{\mathrm{i}}\right\rangle /\left(1+\frac{\mathrm{a}}{2}\right)$

where

$$
\mathrm{a}=\mathrm{m}_{\mathrm{X}} \mathrm{Y}_{\mathrm{X} / \mathrm{O}} \Delta \mathrm{t}
$$

From results on the production of OUR and $\mathrm{CO}_{2}$, some bioprocess parameters can be estimated. Estimation of biomass at a certain time $\left(\mathrm{X}_{\mathrm{n}}\right)$ is calculated assuming values for its yield based on oxygen consumption $\left(\mathrm{Y}_{\mathrm{X} / \mathrm{O}}\right)$ and biomass maintenance coefficient $\left(\mathrm{m}_{\mathrm{X}}\right)$. FERSOL the software was used in the calculations (Rodríguez-León et al., 1988).

\section{RESULTS AND DISCUSSION}

Citric acid production in the tray-type (TT) bioreactor with different percentages of TCB is shown in Figure 2. The best result was $26.3 \mathrm{~g} / 100 \mathrm{~g}$ of dry CB with $80 \%$ TCB and a bed thickness of 4 $\mathrm{cm}$. Citric acid values for $100 \%$ raw $\mathrm{CB}$ were negligible in the TT bioreactors.
In Figure 3 citric acid production in the horizontal drum (HD) bioreactor with different percentages of TCB is presented. In this case, the best result was obtained with $100 \%$ TCB yielding $26.9 \mathrm{~g}$ of citric acid/100g of dry CB. These results show the importance of starch gelatinization, which surely made the starch structure more accessible to fungus attacks.

The effect of percentage of TCB on citric acid production was clearly observed in the HD bioreactor where high degrees of gelatinization were favorable. On the other hand, in the TT bioreactors, it was shown that high levels of gelatinization of $\mathrm{CB}$ starch were unnecessary. This fact can be explained by the excessive compaction of material due to starch gelatinization, which limited the passage of air throughout the medium. In the HD bioreactor there was not high degree of substrate compaction because it was turned three or four times a day and its initial moisture was lower than in the process carried out in the TT bioreactors.

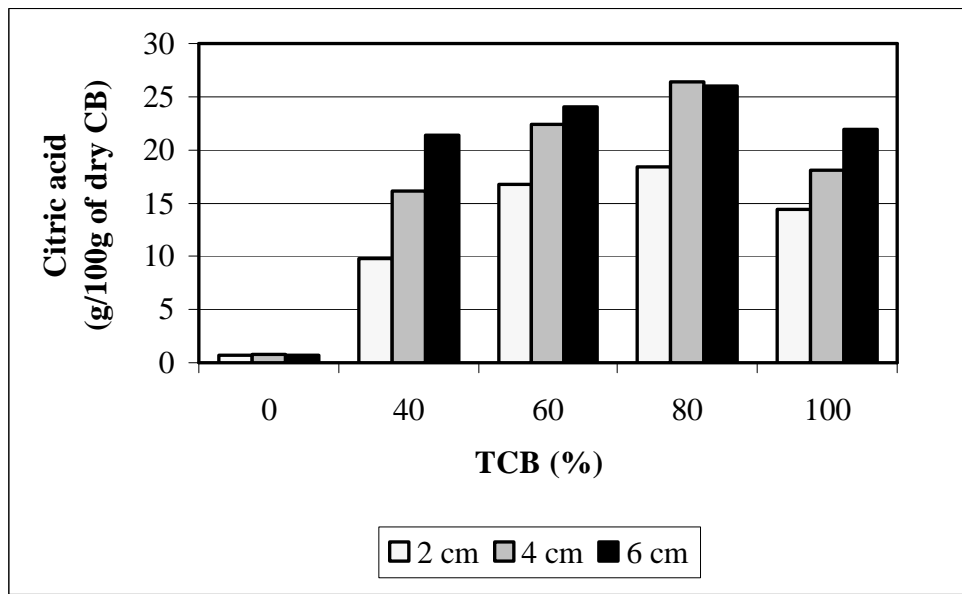

Figure 2: Citric acid production in tray-type bioreactors with 0, 40, 60, 80 and $100 \%$ treated cassava bagasse (TCB) with bed thicknesses of 2,4 and $6 \mathrm{~cm}$. 


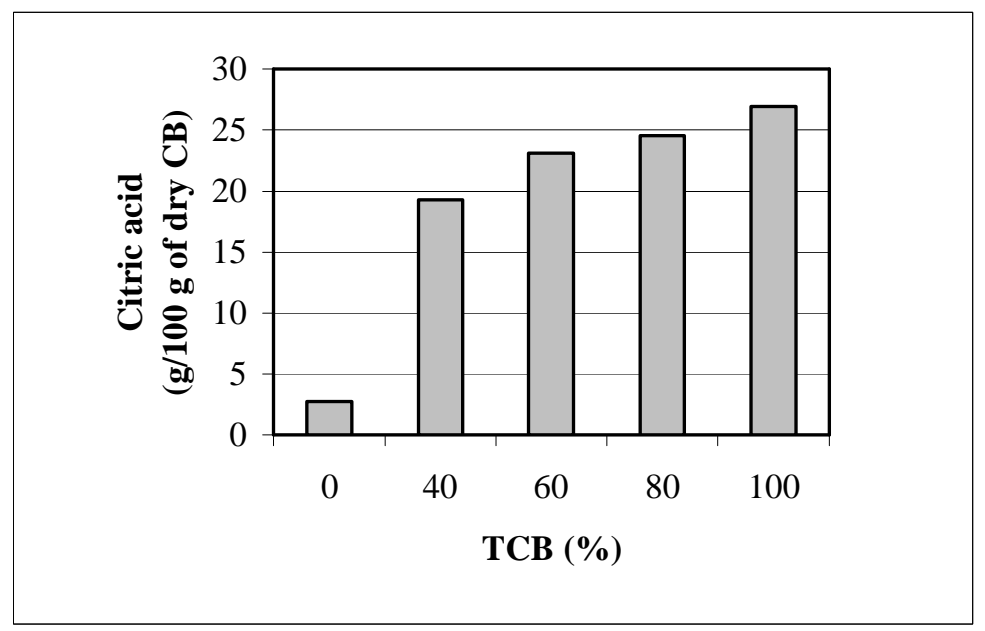

Figure 3: Citric acid production in the horizontal drum (HD) bioreactor with $0,40,60,80$ and $100 \%$ treated cassava bagasse (TCB).

There was no significant difference between the best results obtained in the HD bioreactor ( $26.9 \mathrm{~g}$ of citric acid/100g of dry CB) and in the TT bioreactors (26.3 g of citric acid/100g of dry CB). This proved that aeration was not a determining factor for citric acid production in SSF, as it is in submerged citric acid fermentation (Grewal and Kalra, 1995; Soccol et al., 2003). The study of citric acid production for $A$. niger cultivated by SSF in trays also revealed the importance of an atmosphere rich in $\mathrm{CO}_{2}$. The high partial pressure in $\mathrm{CO}_{2}$ probably delays the release of spores by filamentous fungus, favoring the synthesis of citric acid. Limitation of the growth is an important factor in the production of citric acid. This has been verified in previous studies in Erlenmeyer flasks, where the limitation of growth caused by a higher concentration of $\mathrm{CO}_{2}$ provided a larger accumulation of citric acid (Vandenberghe, 2000).

It was observed that the trays that had thicker beds became more compact during fermentation than the thinner beds. This could be explained by the fact that in more compact substrates layers there was a greater accumulation of $\mathrm{CO}_{2}$ and, consequently, a higher production of citric acid. The values for $80 \%$ TCB did not follow this trend, but in this case citric acid produced in beds with thickness of 4 and $6 \mathrm{~cm}$ were not significantly different, as shown in Table 1. However, citric acid production for 100\% TCB at all bed thickness was lower than that for $80 \%$ TCB due the excessive accumulation of $\mathrm{CO}_{2}$ caused by the high degree of compaction of the substrate.

\section{Table 1: Comparison between citric acid production in the horizontal drum (HD) and that in the tray-type (TT) bioreactors.}

\begin{tabular}{|c|c|c|c|c|}
\hline \multirow{2}{*}{$\begin{array}{c}\text { Amount of } \\
\text { TCB }(\%)\end{array}$} & $\begin{array}{c}\text { Citric acid produced in HD bioreactor } \\
(\mathbf{g} / \mathbf{1 0 0} \mathbf{g} \text { of dry CB) }\end{array}$ & \multicolumn{3}{|c|}{ Citric acid produced in TT bioreactor (g/kg of dry CB) } \\
\cline { 3 - 5 } & & $\mathbf{2 ~ c m}$ & $\mathbf{4} \mathbf{~ c m}$ & $\mathbf{6} \mathbf{~ c m}$ \\
\hline 100 & 26.9 & 14.4 & 18.1 & 21.9 \\
80 & 24.5 & 18.4 & 26.3 & 26.0 \\
60 & 23.1 & 16.8 & 22.4 & 24.0 \\
40 & 19.4 & 9.8 & 16.1 & 21.4 \\
0 & 2.7 & 0.7 & 0.8 & 0.7 \\
\hline
\end{tabular}

Table 1 also shows that citric acid production was higher in the HD bioreactor than in TT bioreactor with a bed thickness of $2 \mathrm{~cm}$ for all percentages of gelatinized $\mathrm{CB}$ starch. Citric acid production was also higher in the HD bioreactor for $0,40,60$ and $100 \%$ TCB than in trays with bed thickness of $4 \mathrm{~cm}$. For only 0 and $100 \%$ TCB, citric acid production in the HD bioreactor was highest than in the tray with a bed thickness of $6 \mathrm{~cm}$.
Another important factor to be considered was fermentation time, which for the trays $(120 \mathrm{~h})$ was shorter than for the HD bioreactor $(144 \mathrm{~h})$. Moreover, energy consumption in the trays was also lower considering the need for intermittent stirring of the substrate in the HD bioreactor, so the costs of the process conducted in the TT bioreactors were lower.

It was shown in Table 1 that the highest production of citric acid was achieved in the HD 
bioreactor using 100\% TCB (26.9 g/100g of dry CB). Thus, a kinetics study was conducted under these conditions in order to observe characteristic parameters and to determine the global yield of the process. In Figure 4 citric acid production, residual starch and $\mathrm{pH}$ evolution observed during SSF of CB using $A$. niger are presented.

The $\mathrm{pH}$ value maintained at the beginning of fermentation was important for a specific biomass formation. Normally, citric acid production occurred after $24 \mathrm{~h}$ of fermentation. Figure 4 shows that cells were only maintained and citric acid was produced as $\mathrm{pH}$ decreased. Thus, the drop in $\mathrm{pH}$ observed during the process (5.82 to 2.66) was due to the formation and accumulation of citric acid.

The best productivity of citric acid, achieved in $144 \mathrm{~h}$ of fermentation, was $26.9 \mathrm{~g} / 100 \mathrm{~g}$ of dry CB. In this time, the amount of starch consumed was 38.97 $\mathrm{g} / 100 \mathrm{~g}$ of dry CB. Thus, the global yield of SSF in the HD bioreactor with $100 \%$ TCB was $69 \%$ starch consumption. Previous studies conducted in vertical glass columns with $20 \mathrm{~g}$ of dry substrate and continuous airflow through the substrate yielded 85\% (Vandenberghe, 2000). It is natural that yield during the scale-up process decreased due to problems such as temperature control, heat production and oxygen transfer. Thus, the yield of $69 \%$ in the HD bioreactor was satisfactory. Although the amount of starch consumed during the process was high (Figure 4), the quantities of residual starch at the end of SSF were still significant. The increase in protein content through production of biomass allows the fermented substrate (after extraction of citric acid) to be used as animal feed.

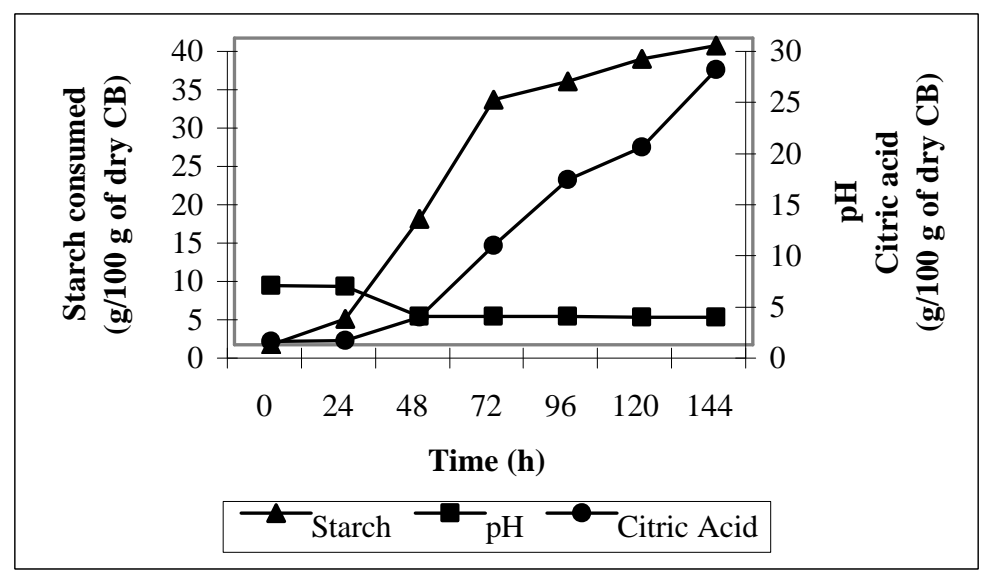

Figure 4: Citric acid production, $\mathrm{pH}$ evolution and starch consumption during SSF of cassava bagasse by Aspergillus niger.

Biomass is a fundamental parameter in the characterization of microbial growth. Its measurement is essential for kinetic studies on SSF. Direct determination of biomass in SSF is very difficult due to problems of separation of the microbial biomass from the substrate. However, the biomass can be estimated from measurements of a specific component. The most readily measured biomass component is protein (Raimbault, 1997). Biomass was analytically determined after $0,24,48$, $72,96,120$ and $144 \mathrm{~h}$ of fermentation. These data are presented in Figure 5. The FERSOL software (Rodríguez-León et al., 1988) allowed determination of the equation (9) coefficients by a successive approach. From the values of OUR and $\mathrm{CO}_{2}$ production, obtained experimentally, the system determined a biomass yield $\left(\mathrm{Y}_{\mathrm{X} / \mathrm{O}}\right)$ of $4.372 \mathrm{~g}$ of biomass per $\mathrm{g}$ of $\mathrm{O}_{2}{ }^{-1}$ consumed and a biomass maintenance coefficient $\left(\mathrm{m}_{\mathrm{X}}\right)$ of $0.0162 \mathrm{~g}$ of $\mathrm{O}_{2}$ consumed per $\mathrm{g}$ of biomass ${ }^{-1} \mathrm{~h}^{-1}$. In Figure 5 the changes in $\mathrm{O}_{2}$ and $\mathrm{CO}_{2}$ percentages during fermentation, such as estimated biomass and analytically determined biomass in the HD bioreactor with $100 \%$ TCB are presented. The production of $\mathrm{CO}_{2}$ did not exceed $0.4 \%$. This result shows that limitation of growth was excessive and the strategy of delaying aeration by 20 hours was probably not favorable to this system. This could also be shown by the production of biomass during fermentation, which was only $0.87 \mathrm{~g} / 100 \mathrm{~g}$ of dry $\mathrm{CB}$. After $50 \mathrm{~h}$ of fermentation $\mathrm{CO}_{2}$ production reached a maximum. At this point, citric acid production was only about $0.3 \mathrm{~g} / 100 \mathrm{~g}$ of dry CB. These facts showed that the microorganism favors citric acid production over biomass formation. The difference between the estimated and the analytically determined biomass in the HD bioreactor, mainly after $72 \mathrm{~h}$ of fermentation, was an indicator that an indirect method of biomass determination, through on-line monitoring of $\mathrm{CO}_{2}$ production, can probably correct the errors in determination of biomass by analytical methods. 


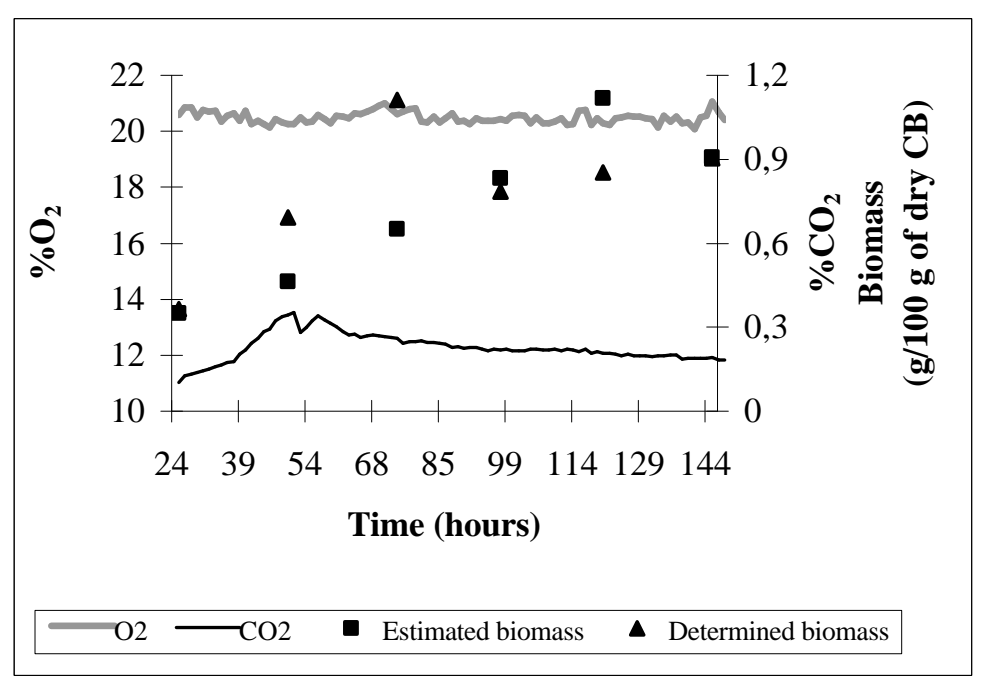

Figure 5: Determined and estimated biomass, $\mathrm{CO}_{2}$ production and $\mathrm{O}_{2}$ consumption during citric acid fermentation of cassava bagasse by Aspergillus niger LPB 21 in the horizontal drum bioreactor.

\section{CONCLUSIONS}

Citric acid production by $A$. niger with CB in SSF was shown to hold promise. $\mathrm{CB}$ was pretreated (starch gelatinization) in order to facilitate starch consumption and, consequently, synthesis of citric acid. The high starch consumption observed for this process contributes to a reduction in environmental pollution.

In this work two types of semi-pilot scale bioreactors were tested: tray and horizontal drum. In citric acid production, the effect of a high degree of gelatinization was more relevant when using the HD bioreactor. In the TT bioreactor, a thicker bed favored higher yields of citric acid. Besides, it represented the use of larger effective volume of the bioreactor.

Although citric acid production was high in the HD bioreactor, the TT bioreactor offers advantages in terms of costs and energy saving. Besides, there was no significant difference between the best production of the acid in the HD $(26.9 \mathrm{~g} / 100 \mathrm{~g}$ of dry $\mathrm{CB})$ and the TT bioreactors $(26.3 \mathrm{~g} / 100 \mathrm{~g}$ of dry $\mathrm{CB})$.

The yield of $69 \%$ in the HD bioreactor was acceptable when compared with those obtained with laboratory-scale bioreactors (glass columns), which were about $85 \%$. This decrease in citric acid production was probably due to the effect of fermentation temperature, which was not controlled in the HD bioreactor.

On-line monitoring of fermentation in the HD bioreactor allowed determination of the relationship between $\mathrm{CO}_{2}$ and $\mathrm{O}_{2}$ evolution, biomass and production of citric acid by A. niger LPB 21. It was observed that low respiration rates contributed to the production of high concentrations of citric acid.

\section{ACKNOWLEDGEMENTS}

F. C. Prado and C. R. Soccol would like to thank CAPES and CNPq, respectively, for the scholarship.

\section{NOMENCLATURE}

$\% \mathrm{CO}_{2 \text { out }}$ percentage of $\mathrm{CO}_{2}$ at

bioreactor outlet

$\% \mathrm{O}_{2 \text { out }}$ percentage of $\mathrm{O}_{2}$ at

bioreactor outlet

$\Delta \mathrm{t} \quad$ time interval considered

$F_{\text {in }} \quad$ bioreactor inlet airflow

$\mathrm{F}_{\text {out }} \quad$ bioreactor outlet airflow

$\mathrm{m}_{\mathrm{X}} \quad$ cell biomass maintenance coefficient

$\mathrm{V}_{\mathrm{CO}_{2} \text { out }} \quad \mathrm{CO}_{2}$ volumetric flow at bioreactor outlet

$\mathrm{V}_{\mathrm{N}_{2} \text { in }} \quad \mathrm{N}_{2}$ volumetric flow at bioreactor inlet

$\mathrm{V}_{\mathrm{N}_{2} \text { out }} \quad \mathrm{N}_{2}$ volumetric flow at bioreactor outlet

$\mathrm{V}_{\mathrm{O}_{2} \text { uptake }}$ volumetric flow of the $\mathrm{O}_{2}$ uptake
( $\mathrm{g}$ of $\mathrm{O}_{2}$ consumed per $\mathrm{g}$ of biomass $\left.{ }^{-1} \mathrm{~h}^{-1}\right)$ 
$\mathrm{V}_{\mathrm{O}_{2} \text { out }} \quad \mathrm{O}_{2}$ volumetric flow at

bioreactor outlet

$\mathrm{X}_{\mathrm{n}} \quad$ cell biomass at a given time

$\mathrm{X}_{\mathrm{i}} \quad$ cell biomass at the end of $\Delta \mathrm{t}$

$\mathrm{X}_{0} \quad$ cell biomass at the beginning of $\Delta \mathrm{t}$

$\mathrm{Y}_{\mathrm{X} / \mathrm{O}}$ cell biomass yield based on the consumption of $\mathrm{O}_{2}$
Okara (Soy-residue) by Solid-state Fermentation, Bioresource Technology, vol. 54, 323-325 (1995).

National Starch Chemical Corporation, NS 00396/855 (1985).

Pandey, A., Solid-state Fermentation, Biochemical Engineering Journal, vol. 13, 81-84 (2003).

Pandey, A., Soccol, C. R., Nigam, P., Soccol, V. T. and Mohan R., Biotechnological Potential of Agro-industrial Residues. II. Cassava Bagasse, Bioresource Technology, vol. 74, 81-87 (2000).

Pandey, A., Soccol, C. R., Rodriguez-León, J. A. and Nigam, P., Production of Organic Acids by Solidstate Fermentation. In: Solid-state Fermentation in Biotechnology - Fundamentals and Applications. New Delhi: Asiatech Publishers, Inc., 113-126 (2001).

Alves, A. A. C. and Silva, A. F. Cultivo da Mandioca para a Região Semi-árida. Jan 2003. Embrapa Mandioca e Fruticultura (2003). Available through <http://sistemasdeproducao.cnpt ia.embrapa.br/FontesHTML/Mandioca/mandioca _semiarido/importancia.htm> Consulted on July 26, 2004.

Aravantinos-Zafiris, G., Tzia, C., Oreopoulou, V. and Thomopoulos, C.D., Fermentation of Orange Processing Wastes for Citric Acid Production, Journal of Science and Food Agriculture, vol. 65, 117-120 (1994).

Cereda, M. P., Caracterização dos Resíduos da Industrialização da Mandioca. In: CEREDA, M. P. Industrialização da Mandioca no Brasil. São Paulo: Paulicéia, 11-50 (1994).

Grewal, H. S. and Kalra, K. L., Fungal Production of Citric Acid., Biotechnology Advances, vol. 13, 209-234 (1995).

Hang, Y. D. and Woodams, E. E., Apple Pomace: A Potential Substrate for Citric Acid Production by Aspergillus niger, Biotechnology Letters, vol. 6, 763-764 (1984).

Hang, Y. D. and Woodams, E. E., Grape Pomace: A Novel Substrate for Microbial Production of Citric Acid, Biotechnology Letters, vol. 7, 253254 (1985).

Hang, Y. D. and Woodams, E. E., Microbial Production of Citric Acid by Solid-state Fermentation of Kiwifruit Peel, Journal of Food Science, vol. 52, 226-227 (1987).

Jianlong, W., Production of Citric Acid by Immobilized Aspergillus niger Using a Rotating Biological Contactor (RBC), Bioresource Technology, vol. 75, 245-247 (2000).

Khare, S. K., Jha, K. and Gandhi, A. P., Short Communication: Citric Acid Production from
Raimbault, M., General and Microbiological Aspects of Solid Substrate Fermentation. International Training Course. Solid-State Fermentation. Curitiba - Paraná, Brazil (1997).

Rodríguez-León, J. A., Sastre, L., Echevarria, J., Delgado, G., Bechstedt, W., A Mathematical Approach for the Estimation of Biomass Production Rate in Solid-state Fermentation, Acta Biotechnologica, vol. 8, 307-310 (1988).

Röhr, M., Kubicek, C. P. and Komínek, J., Citric Acid. In: Reed, G., Rehm, H. J. (Eds.). Biotechnology, vol. 3. Weiheim: Verlag Chemie, 419-454 (1983).

São Paulo, Secretaria de Estado da Saúde, Normas Analíticas do Instituto Adolfo Lutz. São Paulo (1985).

Soccol, C. R., Contribuição ao Estudo da Fermentação no Estado Sólido em Relação com a Produção de Ácido Fumárico, Biotransformação de Resíduo Sólido de Mandioca por Rhizopus e Basidiomacromicetos do Gênero Pleurotus. Thesis (Prof. Titular) - Universidade Federal do Paraná, Curitiba - PR, Brazil (1994).

Soccol, C. R. and Vandenberghe, L. P. S., Overview of applied solid-state fermentation in Brazil, Biochemical Engineering Journal, vol. 13, 205218 (2003).

Soccol, C. R., Prado, F. C., Vandenberghe, L. P. S. and Pandey, A, General Aspects in Citric Acid Production by Submerged and Solid-state Fermentation. In: Encyclopedia on Bioresource Technology. New York: Haworth Press, 652-664 (2003).

Vandenberghe, L. P. S., Développement d'un Procédé pour la Production d'Acide Citrique par Fermentation en Milieu Solide à partir de Résidus de l'Agro-industrie du Manioc, PhD. diss., 
Université de Technologie de Compiègne. Compiègne (2000).

Vandenberghe, L. P. S., Soccol, C. R., Pandey, A. and Lebeault, J.-M., Cassava Bagasse, An Alternative Substrate for Citric Acid Production in Solid-state Fermentation. In: $11^{\text {th }}$ International Biotechnology Symposium and Exhibition, 3-8 Sept. 2000, Berlin. Book of Abstracts. Frankfurt: Dechema, vol. 4, 153-155 (2000a).

Vandenberghe, L. P. S., Soccol, C. R., Pandey, A. and Lebeault, J.-M., Solid-state Fermentation for the Synthesis of Citric Acid by Aspergillus niger, Bioresource Technology, vol. 74, 175-178 (2000b).

Vervack, W., Analyse des Alimentes, Methods Courantes d'Analyses. Louvain-la-Neuve: Laboratoire de Biochimie de la Nutrition (1973).

Yokoya, F., Fermentação cítrica, vol. 1, 79p, Campinas - SP: Fundação Tropical de Pesquisas e Tecnologia André Tosello, 1992. 